\title{
Recommendations for the conservation and management of humpback dolphins Sousa chinensis in the Algoa Bay region, South Africa
}

\author{
L. Karczmarski, V.G. Cockcroft, A. McLachlan and P.E.D. Winter
}

Karczmarski, L., V.G. Cockcroft, A. McLachlan and P.E.D. Winter. 1998. Recommendations for the conservation and management of humpback dolphins Sousa chinensis in the Algoa Bay region, South Africa. Koedoe 41(2): 121-129. Pretoria. ISSN 0075-6458.

The natural history of humpback dolphins Sousa chinensis inhabiting the Algoa Bay region, Eastern Cape, South Africa, was investigated by means of land- and sea-based surveys undertaken between May 1991 and May 1994. This article reviews the findings which are relevant to the conservation of humpback dolphins and provides recommendations for both the conservation and management of this species in Eastern Cape waters. In general, humpback dolphins appear to be typical coastal dolphins which occur in small numbers, have low population growth and depend on restricted inshore resources. Establishment of protected areas where human impact could be limited or controlled seems to be the most effective conservation/management approach. Habitats critical for humpback dolphins in Eastern Cape waters (inshore rocky reefs) and the dolphin's core areas in the Algoa Bay region have been identified. It is recommended that a conservation and management zone (marine sanctuary) in the Algoa Bay region be established and a suitable site for it is identified. Given adequate legislation and proper management, this area could be used for the development of ecotourism, including dolphin-watch operations, which would further stimulate interest in coastal conservation.

Key words: humpback dolphin, Sousa chinensis, natural history, ecology, conservation and management, ecotourism, Algoa Bay, South Africa.

L. Karczmarscki, Centre for Dolphin Studies, Port Elizabeth Museum, P.O. Box 13147, Humewood, 6013, South Africa and Zoology Department, University of Port Elizabeth, P.O. Box 1600, Port Elizabeth 6000 Republic of South Africa (Present address: Oceanic Society, San Francisco and Texas A\&M University at Galveston, Midway Spinner Dolphin Research Project, Midway Island Station \# 2, P.O. Box 29460, Honolulu, HI 96820 - 1860, USA.); V.G. Cockcroft, Centre for Dolphin Studies, Port Elizabeth Museum, P.O. Box 13147, Humewood, 6013 Republic of South Africa; A. McLachlan (Present address: College of Science, SQU, P.O. Box 36, SQU 123, Oman) and P.E.D. Winter, Zoology Department, University of Port Elizabeth, P.O. Box 1600, Port Elizabeth, 6000 Republic of South Africa.

\section{Introduction}

Indian Ocean humpback dolphins Sousa chinensis inhabit inshore waters of the IndoPacific region and are known to occur along the east and south coast of South Africa (Ross et al. 1994). These coastal dolphins do not appear to be abundant anywhere and their inshore distribution renders them particularly susceptible to the effects of human activities in the coastal zone and general degradation of inshore habitats (Reeves \& Leatherwood 1994). Although little is known about the 

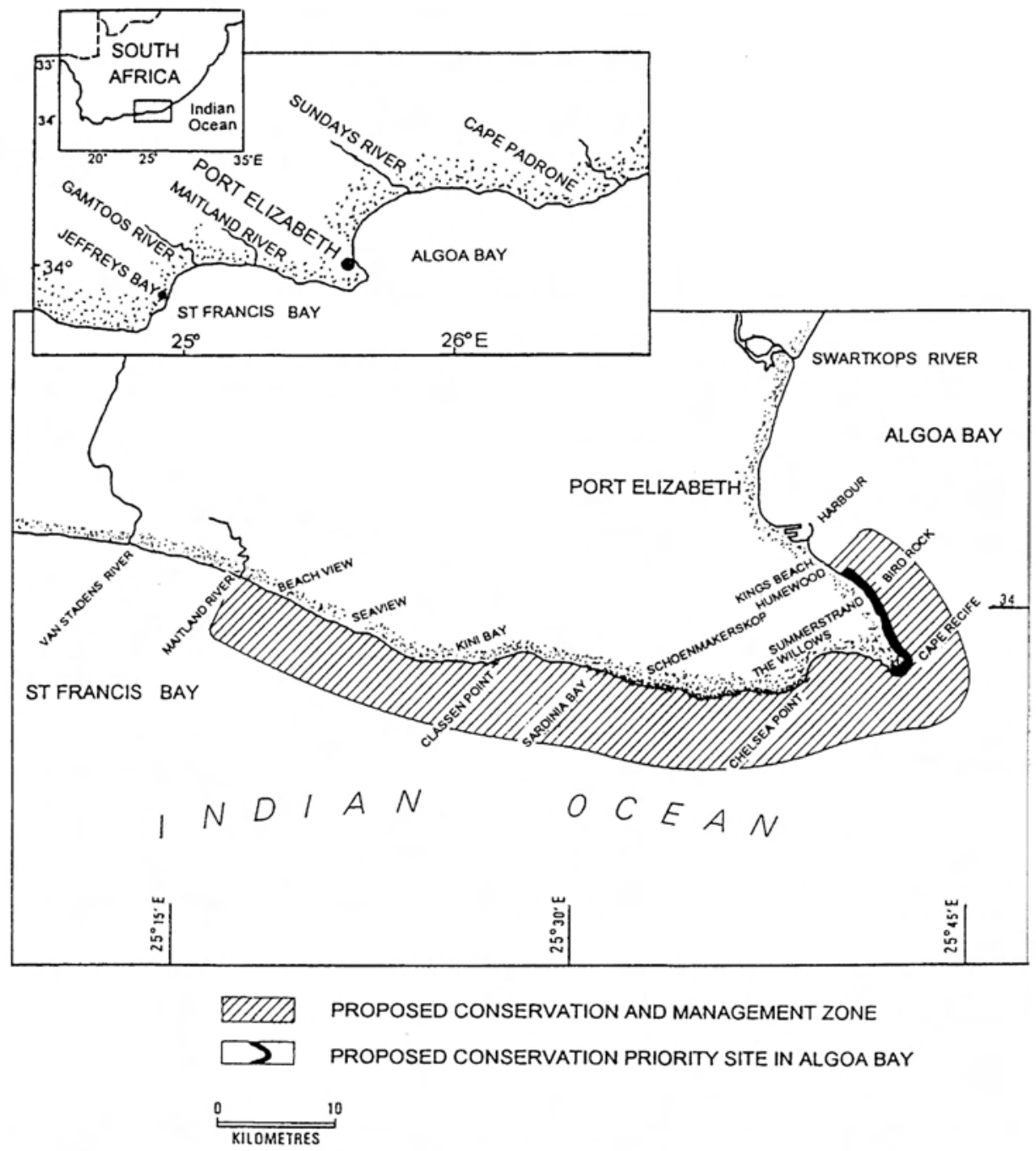

Fig. 1. The Algoa Bay region on the south Eastern Cape coast of South Africa and the proposed conservation and management zone (marine sanctuary) with the conservation priority site in the most south-western bight of Algoa Bay.

scale of human impact on humpback dolphins and almost nothing about the status of particular populations, there is evidence that at least some populations have been seriously depleted and several others may be under considerable stress (e.g. Klinowska 1991; Reeves \& Leatherwood 1994).

In South Africa, the main threat to humpback dolphins are gillnets set to deplete the num- ber of large sharks off the KwaZulu-Natal coast in an attempt to protect bathers at the main bathing beaches (Cockcroft 1990). Furthermore, in KwaZulu-Natal, humpback dolphins seem to accumulate high concentrations of toxic organochlorines which may affect negatively both the reproductive efficiency of males and survival of the newborn offspring of primiparous females (V.G. Cockcroft, unpublished data). Cockcroft 
(1990) warned that human-caused mortality may be close to or exceed the likely replacement rate of the humpback dolphin population in KwaZulu-Natal.

The delineation of appropriate conservation and management strategies for any wildlife species requires that several biological and population parameters be known or adequately estimated. However, despite their inshore distribution, humpback dolphins remain little known, with much of our knowledge based on fragmentary information (e.g. Saayman \& Tayler 1979; Durham 1994). Only recently an intensive field study conducted in the Algoa Bay region, Eastern Cape, South Africa (Karczmarski 1996a) provided considerable amount of data on their natural history. This work is more detailed, with more data collected over a longer term than in any other location to date. This article presents a brief review of findings which are relevant to the conservation of humpback dolphins and should be considered in integrated coastal zone management. Furthermore, it provides recommendations for the conservation and management of humpback dolphins in Algoa Bay, which could and should be used as a guideline by town planners, developers and conservation authorities in order to ensure that the activities of both humans and humpback dolphins in inshore waters of the Algoa Bay region will be compatible.

\section{The area}

Algoa Bay is the easternmost and largest of several log spiral bays found on the southeast coast of South Africa (Fig. 1). The Bay is flanked on the western side by Cape Recife $\left(34^{\circ} 02^{\prime} \mathrm{S} ; 25^{\circ} 42^{\prime} \mathrm{E}\right)$ and on the eastern side by the less prominent Cape Padrone $\left(33^{\circ} 46\right.$ 'S; $\left.26^{\circ} 28^{\prime} \mathrm{E}\right)$. Over most of Algoa Bay the depth is $<50 \mathrm{~m}$. The bay experiences semi-diurnal tides; mean spring and neap tidal ranges are $1.61 \mathrm{~m}$ and $0.51 \mathrm{~m}$, respectively.

\section{Methods}

Systematic sea- and land-based surveys were undertaken over approximately $55 \mathrm{~km}$ of coastline of the south-western part of Algoa Bay (Fig. 1) from May 1991 to May 1994. Daily land-based surveys usually started 1-2.5 hours after sunrise (weather permitting) and observations of the inshore waters, to approximately $1 \mathrm{~km}$ offshore, were carried out from several visually overlapping vantage points. Seabased surveys were opportunistic, limited by both the presence of dolphins and weather conditions and were conducted using a $3.5 \mathrm{~m}$ inflatable boat powered by a $30 \mathrm{HP}$ outboard engine. The procedure applied during these surveys is described in detail in Karczmarski et al. (in press).

During boat surveys, dolphins were photographed using a motorised camera equipped with a variable length $(70-210 \mathrm{~mm}$ ) lens and 100 ASA colour positive film. Individuals were subsequently identified following the procedure described by Karczmarski \& Cockcroft (in press a). At sea, the maximum possible time was dedicated to following dolphin groups and recording their membership (ID photographs), activities and habitat use. When weather or sea conditions precluded boat surveys, dolphin activity and movement was monitored from land-based vantage points.

Estimates of group size and composition were repeated several times during a survey. Group activity/behaviour (the predominant activity of the majority of the group members) was recorded in 5-minute intervals. The location of dolphin groups, as well as direction of movement were repeatedly recorded using land-marks and subsequently plotted on a chart. Water clarity (Secchi Disc depth) was recorded during boat surveys, starting from January 1992. The water depth was estimated from hydrographic charts (S.A. Navy) and bathymetry maps (S.A. Geological Survey).

The number of sightings (groups or solitary animals) recorded in Algoa Bay was corrected for effort (number of hours). The stretch of coastline with the highest number of sightings was then divided into 31 sectors, each approximately $500 \mathrm{~m}$ in length. A Coefficient of Area Use (AU), which ranges from $0.0-1.0$ and represents the time spent by dolphins in a particular sector as a proportion of the total observation time in that day, was calculated for each of these sectors as

$$
\mathrm{AU}=\mathrm{D} / \mathrm{T} \text { where: }
$$

AU - Coefficient of Area Use

D - time spent by dolphins in a particular sector, $\mathrm{T}$ - total observation time on any one day

If the localisation of dolphins in a particular sector was not clear, with the animals moving back and 
forth between two neighbouring sectors, they were considered to be in both sectors. Subsequently, a mean Coefficient of Area Use was calculated for each of the 31 sectors. General structure of the seabed (proportion of rocky reefs to sandy bottom) in each of these sectors was assessed using aerial photographs (photographs by W.L. Illenberger, Long Term Monitoring Program, Institute for Coastal Research, University of Port Elizabeth) and side scan sonar data (H. Phipps, S.A. Geological Survey, Cape Town).

For comparative purposes, several boat surveys were performed in the south-western part of St. Francis Bay, along about $20 \mathrm{~km}$ of coastline, with the most southerly point at Cape St. Francis (Fig. 1). Occasional shore-based surveys took place in Sardinia Bay, Sea View/Maitlands River beach, off Van Stadens River mouth, Gamtoos River mouth and in Jeffreys Bay (Fig. 1).

Two seasons, summer and winter, are distinguished here (for the definition see Karczmarski et al. in press). In general, early May marks the beginning of "winter" and late October marks the beginning of "summer".

\section{Summary of relevant findings}

Groups and solitary humpback dolphins were observed 113 times (over 320 hours of direct observation). The majority of these (104 observations) were in Algoa Bay. Seventy seven sea-based surveys were completed (189 hours of direct dolphin observations); 68 in Algoa Bay and nine in St. Francis Bay. Photographs recording group membership were taken during 60 sea surveys, of which 58 were in Algoa Bay.

In Algoa Bay, sightings were recorded with similar frequency throughout the tidal cycle and occurred throughout a wide range of water clarity $(\min .=2.25 \mathrm{~m} ; \max .=12.0 \mathrm{~m})$, with mean Secchi reading of $4.5 \mathrm{~m}$ during both winter $(n=16)$ and summer $(n=31)$ and no apparent preference for any particular water clarity conditions. Sightings were most frequent, however, in the early morning, decreased rapidly by midday, and subsequently increased in the evening. A similar daylight occurrence pattern emerges from opportunistic sightings $(n=109)$ collected for Algoa Bay between 1970 and 1991 (V.G. Cockcroft, unpublished data). It seems likely that the daylight occurrence and movement of humpback dolphins in Algoa Bay follows the diurnal cycles of their prey (Karczmarski 1996a). The nocturnal occurrence and activity of humpback dolphins in Algoa Bay remain unknown.

Sightings occurred predominantly within $150-400 \mathrm{~m}$ of the shore, in water less than 15 $\mathrm{m}$ deep. Only during 6 sightings (5.3\%) were dolphins in Algoa Bay seen venturing $>500$ $\mathrm{m}$ from the shoreline, but were never seen in water deeper than $25 \mathrm{~m}$. In all these instances, the events were short term, with the animals moving back inshore after about an hour. In general, water depth appears to be the main factor limiting the inshore distribution of humpback dolphins and the isobath of about $25 \mathrm{~m}$ seems to represent the critical depth (Karczmarski 1996a).

Births of humpback dolphins in the Algoa Bay region occur predominantly in summer (Karczmarski 1996a). The rate of discovery of newly identified dolphins and individual sighting frequencies suggest that humpback dolphins from Algoa Bay are part of a substantially larger population which utilises a considerable length of the coastal zone. Although it remains unknown if this larger population is open or closed, the estimate of the population size ranges between circa 200 and 500 animals (for closed and open population models, respectively) with a relative density of 0.42 dolphins per kilometre of coast. As the $25 \mathrm{~m}$ isobath is seldom more than $1 \mathrm{~km}$ offshore, this translates to 0.42 dolphins per square kilometre. The mean annual crude birth rate is less than 5\% and the recruitment rate to the age of one year approximates $3.7 \%$. Estimated population parameters seem unlikely to allow population growth (Karczmarski 1996a, Karczmarski \& Cockcroft 1997).

During the majority of sightings in Algoa Bay $(70.5 \%)$ humpback dolphins moved westwards (past Cape Recife, towards St. Francis Bay). The remainder (29.5\%) moved in a north-easterly direction along the sandy shore of Algoa Bay. This pattern was similar for both summer $(67.7 \%$ and $32.3 \%)$ and 
winter $(74.1 \%$ and $25.9 \%)$. All but one humpback dolphin seen in St. Francis Bay were observed previously in Algoa Bay, in sites > $110 \mathrm{~km}$ distant (Karczmarski 1996a).

Solitary humpback dolphins were seen throughout the year and constituted $15.4 \%$ ( $n=16)$ of sightings. Groups varied in size from three to 24 animals but were seldom larger than 13 with a mean of seven $(n=88$, $s d=2.52$ ). Generally the group size remained unchanged throughout the observation time and was not affected by ebb and flood tides (Mann-Whitney, $U=459.50, n=$ $97, P=0.50$ ) or time of day (Kruskal-Wallis ANOVA, KW $=14.47, n=146, P=0.11$ ). However, the mean group size and the monthly numbers of sightings per unit effort varied considerably throughout the year, with relatively little difference in the pattern between years. In general, although humpback dolphins were observed in Algoa Bay throughout the year, there was a significant pattern of seasonal occurrence with an increase in the number of sightings per unit effort and mean group size in summer and late winter (Kruskal-Wallis ANOVA, KW = 26.68, $n=102, P=0.005$ and $\mathrm{KW}=28.65$, $n=88, P=0.003$, for the number of sightings per unit effort and group size, respectively). This seasonal variability follows a regular seasonal fluctuation in water temperature, coincides with the dolphins' reproductive seasonality and seems to be related to the apparent seasonal changes in the abundance and distribution of the inshore prey resources (Karczmarski \& Cockcroft 1997; Karczmarski et al. in press).

During most surveys in Algoa Bay, humpback dolphins remained for several hours within the $15 \mathrm{~km}$ long stretch of coastline between Cape Recife and Port Elizabeth harbour (Fig. 1). Dolphin activity was not evenly distributed over this most extensively used stretch of the Algoa Bay coastal zone and a preference for shallow rocky reefs was evident throughout the year. The Coefficient of Area Use (AU) varied significantly between the 31 sectors of coastline (Kruskal-Wallis ANOVA, $\mathrm{KW}=192.29, n=640, P<0.0001$ ) and was significantly correlated with the dis- tribution of natural and man-made reefs (Spearman Rank Correlation, $r=0.73, n=$ $31, P<0.0001)$ with little difference between summer and winter (Mann-Whitney, $U=$ $454.00, n=31, P=0.71)$. Open stretches of coastline, sandy shores and areas with extensive human activity (sea-traffic, tourists, etc.) were used infrequently. Humpback dolphins were only sporadically seen northeastwards off the Port Elizabeth harbour and the groups progressing in a north-easterly direction were amongst the smallest seen (Karczmarski \& Cockcroft 1997; Karczmarski 1996a).

In the most extensively used sectors, the dominant activity was foraging/feeding. The frequency of this behaviour correlated significantly with the distribution of shallow rocky reefs (Spearman Rank Correlation, $r=$ $0.70, n=29, P<0.0001$ ), presumably primary feeding grounds for humpback dolphins in the Algoa Bay region. Travelling was significantly negatively correlated with the distribution of inshore reefs (Spearman Rank Correlation, $r=-0.60, n=29, P=$ 0.0006), but represented the dominant behaviour in sectors with low AU values which were probably used as "transit zones" between different feeding grounds in the Algoa Bay region. Of the nine sightings of humpback dolphins recorded outside Algoa Bay, foraging/feeding was observed only along rocky shores, while travelling was seen along both rocky and sandy coastal zones (Karczmarski 1996a).

The proportion of time spent in different behaviours varied throughout the day and formed a distinct pattern which apparently follows the solar day, is dominated by foraging/feeding and shows only minor differences between summer and winter. Generally, foraging/feeding peaked in the morning, gradually decreased through the rest of the day and occasionally, particularly in winter, increased again in the evening. There was little tidal impact on the diurnal behaviour of humpback dolphins in Algoa Bay (Karczmarski 1996a; Karczmarski \& Cockcroft in press $\mathrm{b}$ ). 
These animals, however, frequently altered their behaviour when disturbed by inshore boat traffic (Karczmarski et al. 1997). During the sea-based surveys, it usually took at least 30-40 minutes of slow and gentle approach, with the boat at a distance of at least 25 meters from the group, before the animals appeared to have become habituated to the presence of the research boat. Humpback dolphins were not affected by the presence of bathers and/or surf-boards, but appeared to be particularly disturbed by powerboats and on numerous occasions ( $n=$ 64) were seen actively avoiding fast moving vessels $(95.3 \%$ of incidents). The foraging/feeding along the Port Elizabeth harbour wall, although relatively frequent (mean $\mathrm{AU}=0.17, s d=0.11$ ), was seen only in the early morning, and the area was generally avoided when the inshore traffic increased (Karczmarski 1996a).

\section{Implications for conservation and management}

In summary, humpback dolphins appear to be typical coastal dolphins, which occur in small numbers, have low population growth and depend on restricted inshore resources. As such, they are particularly vulnerable to negative environmental pressure. Loss or drastic alteration of their critical habitats, frequent incidental mortality or heavy overexploitation (e.g. incidental entanglement, bycatch) may reduce the local population to a size where demographic or environmental stochastic events could possibly represent a threat to its continuous biological existence (Gilpin \& Soulé 1986).

Identification and subsequent protection of habitats critical to dolphins seems one way of ensuring a sufficient amount of space, shelter and food for the animals (Karczmarski 1996a). In Eastern Cape waters, the inshore, shallow reefs need to be recognised as the habitat of primary importance for humpback dolphins. Destruction of rocky shorelines could destroy dolphin feeding grounds and/or reduce the nursery areas of dolphin prey species.
The present level of industrialisation and urbanisation of the Algoa Bay region is low. During the last pollution survey (Gardner $e t$ al. 1985) the Bay was considered relatively unpolluted and it seems apparent that the situation has changed very little since. The dolphins in Algoa Bay, as well as in Eastern Cape waters in general, are not subjected to heavy depletion known to occur in other areas (e.g. capture in nets along the KwaZulu-Natal coast, Cockcroft 1990). Furthermore, levels of accumulated pollutants are lower than those of animals from some other areas (Cockcroft et al. 1989, 1991) and are unlikely to represent a threat. Consequently, it seems apparent that the Algoa Bay region currently represents a relatively unspoiled environment which may support a continuous presence of humpback dolphins.

Nevertheless, only a very restricted section of the Algoa Bay coastal zone is actively used by these animals. Consequently, a large scale alteration of the concerned area-the dolphin primary feeding ground in Algoa Bay-or commercial development leading to an increase in human activity, could negatively impact on humpback dolphins and possibly cause a range shift. Destruction of natural shorelines and feeding grounds is seen as one reason for the decrease in sightings of bottlenose dolphins in several sectors of Sarasota Bay, western Florida (Wells 1993).

Inshore powerboat traffic has been identified as serious disturbance factor for humpback dolphins in Algoa Bay. In South African waters all cetaceans are protected by the Sea Fishery Act (Act No. 12 of 1988, regulations 18 and 19), and any disturbance of dolphins is outlawed. However, as tourism is a growing industry in the Eastern Cape and watersports an important attraction of the region, humpback dolphins are frequently subjected to human/boat harassment. It seems especially so during summer (L. Karczmarski pers. obs.), which further intensifies the call for concern as summer represents the calving season for humpback dolphins in the Algoa Bay region. Young, inexperienced calves are 
likely to be particularly susceptible to the disturbance caused by powerboats.

Considering the above, establishment of a conservation and management zone ("Marine Sanctuary" sensu Salm \& Clark 1989 ) in the Algoa Bay region is strongly recommended. This area should incorporate the whole stretch of rocky coastal zone between Humewood Beach in Algoa Bay and Maitlands River mouth, with its seaward boundary following the 20-25 m depth contour (Fig. 1). Within this conservation area, any coastal developments which include shoreline alteration, removal of coastal reefs and/or increase in inshore boating should be planned carefully and in consultation with the appropriate conservation authority. The most north-eastern part of the proposed sanctuary (the most south-western stretch of the Algoa Bay's coastal zone) should be declared a conservation priority site, minimum $12 \mathrm{~km}$ long and $800 \mathrm{~m}$ wide (Fig. 1), with limited boat traffic and prohibition of shoreline development. This area should be recognised as a "go slow" zone for any engine-powered craft, with speed limit of 6 knots. Outside this area, an introduction of "go slow" zones around sites apparently frequented by humpback dolphins is strongly recommended. A continuous monitoring of dolphin responses to current levels of human impact is essential.

On the other hand, the presence of the threatened Indian Ocean humpback dolphin in Eastern Cape waters, with the predictable seasonal and daily occurrence and behaviour patterns, could be exploited for ecotourism. Moreover, bottlenose dolphins Tursiops truncatus which are known to occur in Eastern Cape waters in exceptionally large groups, display similarly predictable patterns of occurrence and behaviour (Karczmarski 1996b). The main core-areas used by both dolphin species in Algoa Bay have been identified and are suitable for both shoreand limited/regulated boat-based dolphin watch operations. Furthermore, in winter, when numbers of both bottlenose and humpback dolphins decrease in Algoa Bay, two species of great whales, the humpback
Megaptera novaeangliae and the southern right whale Eubalaena australis, can regularly be seen in the region (Karczmarski 1996b). Both whale species engage in annual, winter migrations from polar feeding grounds to their breeding grounds in subtropical and temperate waters and are easily accessible for both shore- and boat-based watching in Algoa Bay and environs. In conclusion, the Algoa Bay region provides excellent conditions for shore- and boatbased dolphin and whale watching throughout the year. Given adequate legislation and proper, regulated management, dolphin and whale watch groups could attract a number of tourists into the Eastern Cape and stimulate interest in coastal conservation. With the numbers of both humpback and bottlenose dolphins apparently continuously declining along the KwaZulu-Natal coast (Cockcroft 1990; Cockcroft \& Krohn 1994), the Eastern Cape seems to represent currently the true "dolphin coast" of South Africa.

It needs to be stressed, however, that the carrying capacity of Algoa Bay for boat-based dolphin and whale watching operations is limited. It should not exceed four average size ski-boats (about $10 \mathrm{~m}$ ), with a maximum of two of these operating in the area between Cape Recife and the Port Elizabeth harbour at a time. Only one boat should accompany a dolphin group at a time. Furthermore, boatbased dolphin watching would need to be conducted carefully to avoid disturbance of the animals and use of "common sense" during such operations would be essential (see the guideline on how to interact with freeranging dolphins in Karczmarski 1997). When appropriately approached and followed (e.g. during the sea-based research surveys in Algoa Bay, Karczmarski 1996a), the animals "tolerated" the company of a slow moving and "gently behaving" research boat for even several hours $(\mathrm{min} .=45 \mathrm{~min}$, $\max .=5 \mathrm{~h}$ ) at a time, with apparently little or no disturbance. For commercial dolphin or whale watch operations, however, due to their persistent and repetitive nature, the duration of time spent following a dolphin group should not exceed $30 \mathrm{~min}$ at a time. The cumulative length of time the animals 
would be exposed to the presence of a dolphin watch boat should not exceed four hours a day. A "safe" distance of at least $30 \mathrm{~m}$ from a dolphin group should be kept throughout the entire duration of a dolphin watch operation.

Although adequate regulations and management are critical, it is believed that with general reduction of inshore powerboat traffic and introduction of "go slow" zones around the dolphin preferred areas, carefully conducted boat-based dolphin watching would not represent a threat to the animals. Nevertheless, the dolphin watch operations would need to be closely monitored and it is recommended that, when initiated, an appropriate research project assess possible impacts on the animals involved.

The inshore squid fishery off the Eastern Cape is an important, growing industry. Interviews with local fishermen indicate a degree of antagonism towards inshore dolphins as potential competitors (L. Karczmarski pers. obs.). However, although squid forms an integral part of humpback dolphin diet (Barros \& Cockcroft 1991), dolphins are seldom seen in direct interaction with squid-fishing boats (L. Karczmarski pers. obs.). Furthermore, the feeding grounds of humpback dolphins (as well as bottlenose dolphins, L. Karczmarski pers. obs.) are hundreds of meters distant from the area on which the squid fishery concentrates. Consequently, although the interactions between dolphins as top predators and the squid fishery requires more investigation, it seems apparent that there is little direct interaction at present in the Algoa Bay region.

Although the extent of long-range movement of humpback dolphins from Algoa Bay remains unknown, movement over distances exceeding $110 \mathrm{~km}$ was documented and an extensive population range approximating a few hundred kilometres seems possible (Karczmarski 1996a). Consequently, to be effective, conservation measures should not be restricted to a limited area, like for instance exclusively the Algoa Bay region.
Protection of habitats critical for humpback dolphins should be addressed on a national, or even international level. The recommendations presented here for the Algoa Bay region need be seen as part of a larger scale effort, which should be given high priority in integrated coastal zone management. Furthermore, the effort of conserving humpback dolphins is ideally suited to attract public attention, thus strengthening the call for conservation of the coastal marine environment and management of its biological resources in general. This should be capitalised not only in the Eastern Cape but along the whole of the east and south coast of South Africa.

\section{Acknowledgements}

This study would not have been possible without the financial assistance of the Foundation for Research Development (FRD) and WWF South Africa, which is gratefully acknowledged. We thank Ian Hoare for his help with the preparation of Figure 1. The senior author wishes to thank Meredith Thornton, An De Ruyck, Mary Wilmot, Andrzej Bona-Wysocki, Denise Hoare, Cindy and Pierre Botha for their invaluable support during various stages of the work.

\section{References}

Barros, N.B. \& V.G. Cockcroft. 1991. Prey of humpback dolphins (Sousa plumbea) stranded in eastern Cape Province, South Africa. Aquatic Mammals 17(3): 134-136.

Cockcroft, V.G. 1990. Dolphin catches in the Natal shark nets, 1980 to 1988. South African Journal of Wildlife Research 20(2): 44-51.

Cockcroft, V.G. \& R. Krohn. 1994. Passive gear fisheries of the southwestern Indian and southeastern Atlantic oceans: an assessment of their possible impact on cetaceans. Reports of the International Whaling Commission (Special Issue 15): 317-328.

Cockcroft, V.G., A.C. DE Kock, D.A. LORD \& G.J.B. Ross. 1989. Organochlorines in bottlenose dolphins Tursiops truncatus from the East Coast of South Africa. South African Journal of marine Science 8: 207-217.

Cockcroft, V.G., G.J.B. Ross, A.D. Connell, B.D. GARDNER \& A.C. ButLER. 1991. Occurrence of organochlorines in stranded cetaceans and seals from the east coast of southern Africa. Pp. 
271-276. In: LEATHERWOOD, S. \& G.P. DONOVAN (eds.). Cetaceans and cetacean research in the Indian Ocean Sanctuary. (Marine Mammal Technical Report; no. 3. UNEP).

Durham, B. 1994. The distribution and abundance of the humpback dolphins (Sousa chinensis) along the Natal coast, South Africa. M.Sc. thesis, University of Natal, Durban.

Gardner, B.D., A.D. Connell, G.A. Eagle, A.G.S. MOLDAN \& R.J. WatLING. 1985. South African Marine Pollution Survey Report 1979-1982. Pretoria: Council for Scientific and Industrial Research, National Scientific Programmes Unit. (South African National Scientific Programmes report; no. 115).

GILPIN, M.E. \& M.E. SouLÉ. 1986. Minimum viable populations: processes of species extinction. Pp. 19-34. In: SOULÉ, M.E. (ed.) Conservation biology: the science of scarcity and diversity. Sunderland, Mass.: Sinauer.

KarCZMARSKI, L. 1996a. Ecological studies of humpback dolphins Sousa chinensis in the Algoa Bay region, Eastern Cape, South Africa. Ph.D. thesis, University of Port Elizabeth, Port Elizabeth.

KaRCZMARSKI, L. 1996b. Cetacean occurrence pattern in the Algoa Bay region: a possibility for education and ecotourism. Pp. 20-27. In: Proceedings, Sixth PAAZAB Conference, Port Elizabeth, South Africa, 1995. Pretoria: South African Zoological Gardens.

KarCZMARSKI, L. 1997. Powerboats: are they a dolphins friend or foe? Power Boat and Ski February 1997: 44-45, 52.

Karczmarski, L. \& V.G. CockCroft. 1997. Socioecology and population biology of humpback dolphins (Sousa chinensis) in the Algoa Bay region. South Africa: an overview. Document SC/49/SM23, Scientific Committee of the International Whaling Commission, 49th IWC meeting, Bournemouth, U.K.

KARCZMARSKI, L. \& V.G. COCKCROFT. (In press) a. Matrix photo-identification technique applied in studies of free-ranging bottlenose and humpback dolphins. Aquatic Mammals.

KaRCZMARSKI, L. \& V.G. COCKCROFT. (In press) b. Daylight behaviour of humpback dolphins Sousa chinensis in Algoa Bay, South Africa. Zeitschrift für Säugetierkunde.

Karczmarski, L., M. Thornton \& V.G. Cockcroft. 1997. Description of selected behaviours of humpback dolphins Sousa chinensis. Aquatic Mammals 23(3): 127-133.

KarCZMARSkI, L., V.G. COCKCroft \& A. MCLACHLAN (in press). Group size and seasonal pattern of occurrence of humpback dolphins Sousa chinensis in Algoa Bay, South Africa. South African Journal of Marine Science.

Klinowska, M. 1991. Dolphins, porpoises and whales of the world. The IUCN red data book. Gland: IUCN.

ReEves, R.R. \& S. Leatherwood. 1994. Dolphins, porpoises and whales. (1994-1998 action plan for the conservation of Cetaceans). Gland: IUCN/SSC Cetacean Specialist Group.

Ross, G.J.B., G.E. Heinsohn \& V.G. Сосксroft. 1994. Humpback dolphins Sousa chinensis (Osbeck, 1765), Sousa plumbea (G. Cuvier. 1829) and Sousa teuszii (Kukenthal, 1892). Pp. 23-42. In: RidGWAY, S.H. \& R. HARRISON (eds). Handbook of marine mammals, vol. 5: The first book of dolphins. San Diego: Academic Press.

SaAyman, G.S. \& C.K. Tayler. 1979. The socioecology of humpback dolphins (Sousa sp.). Pp. 165-226. In: WinN, H.E. \& B.L. OlLA (eds). Behaviour of marine animals. Vol. 3: Cetaceans. New York: Plenum Press.

SALM, R.V. \& J.R. Clark. 1989. Marine and coastal protected areas: a guide for planners and managers. Gland, Switzerland: IUCN.

WELLS, R.S. 1993. The marine mammals of Sarasota Bay. Pp. 9.2-9.23. In: Sarasota Bay National Estuary Program. Framework for Action. Mote Marine Laboratory, Sarasota, Florida, USA. 